\title{
El cuerpo occidental de la iglesia de San Pedro de Arlanza. Propuesta de reconstrucción histó- rica
}

\author{
María Victoria Herráez Ortega \\ María Dolores Teijeira Pablos
}

\begin{abstract}
RESUMEN. La iglesia del Monasterio de San Pedro de Arlanza presenta en su extremo occidental un cuerpo cuadrangular que surgió probablemente con el objetivo de cobijar adecuadamente el sepulcro del conde Fernán González, fundador de la casa condal castellana. A principios del siglo XVI dicho espacio, una vez perdida su función funeraria, sufrió una profunda reforma con la construcción de un coro alto. Posteriormente, la monumentalización del acceso a la iglesia desde el exterior del monasterio, durante la Edad Moderna, implicó la modificación de la zona noroccidental del mismo.

Palabras clave: Monasterio de San Pedro de Arlanza / Espacio funerario / Espacio coral / Reconstrucción histórica.

ABSTRACT. The church of the Monastery of San Pedro de Arlanza shows in its western end a quadrangular body which arose probably with the objective of housing adequately the tomb of Count Fernán González, the founder of the Castilian Count House. In early 16th century such space, once it had lost its funerary function, underwent a profound reformation as a high choir was built. Later on, in modern times, when the church was made accessible from outside the monastery, its northwestern part had to be modified.

Key words: Monastery of San Pedro de Arlanza, funerary space, choral space, historical reconstruction.
\end{abstract}

\section{INTRODUCCIÓN}

El monasterio de San Pedro de Arlanza, tal como puede observarse hoy, es el fruto de una actividad constructiva prácticamente ininterrumpida, llevada a cabo desde el siglo XI hasta el XIX, y de la ruina progresiva que ha tenido lugar desde el proceso desamortizador hasta prácticamente nuestros días. Como ocurre en cualquier edificio funcional $\mathrm{y}$ vivido, los distintos usos, necesidades y modas que se sucedieron a lo largo del tiempo provocaron una dinámica de expansión y reformas que se tradujeron en la progresiva modificación de la estructura original y en la yuxtaposición, e incluso mezcla, de fábricas diferentes. Esta circunstancia y el progresivo deterioro al que se han visto sometidas sus ruinas, son probablemente las causas por las que el monasterio arlantino prácticamente ha carecido de estudios monográficos especializados después del primer cuarto del siglo XIX.

Sin duda, es importante deslindar los 
diferentes elementos constructivos, tanto para desentrañar la historia del monasterio -y en el caso de Arlanza hay que destacar el gran peso que en el conjunto tiene el valor histórico-, como para acometer una labor de restauración respetuosa y adecuada al carácter de cada una de las dependencias. El propósito del presente trabajo es el estudio del cuerpo occidental de la iglesia, en el que la superposición de fábricas de distintos períodos, la ruina acaecida en las dos últimas centurias y la dispersión de materiales artísticos dificultan la interpretación histórico-artística y funcional ${ }^{1}$.

El monasterio de San Pedro de Arlanza se ha vinculado tradicionalmente al origen del condado de Castilla. La fama del más insigne de los caballeros que se enterraron entre sus muros, Fernán González, ha sido cultivada activamente por los monjes de San Pedro en pro de aumentar la gloria de esta casa conventual. La idea de antigüedad unida a la de prestigio serían los elementos necesarios para conseguir privilegios y prebendas especiales.

En ese contexto no es extraño que, según la tradición, fuera el propio conde castellano quien había fundado el monasterio, reedificándolo sobre un antiguo cenobio de época visigótica ${ }^{2}$.

\footnotetext{
${ }^{1}$ Este trabajo tiene su origen en la Memoria Histórico-artística del Plan Director del monasterio de San Pedro de Arlanza, elaborado bajo la dirección del arquitecto D. Melquíades Ranilla.

${ }^{2} \mathrm{Su}$ origen ha llegado a vincularse al rey godo Wamba (A. DE YEPES, Crónica de la Orden de San Benito, Irache-Valladolid, 1609-1621, f. 375v.; E. FLÓREZ, España Sagrada, Madrid, 1772 vol. XXVII, Madrid, 1772, pp. 81-154). La idea de una nueva fundación por parte del héroe castellano partía de la existencia de una escritura fundacional fechada en el año 912 y suscrita por Fernán González y su esposa Sancha. Sin embargo, la autenticidad de este documento fue puesta en duda ya a finales del siglo XVI por Ambrosio de Morales debido a razones de incongruencia cronológica. Pérez de Urbel ha sugerido que en realidad debió existir una confirmación, realizada por el conde hacia el año 931,
}

Con independencia de la problemática que plantean los documentos, $\mathrm{y}$, por tanto, del desconocimiento de una fecha concreta para datar la fundación del monasterio, parece fuera de duda que la comunidad monástica de Arlanza existía ya en el siglo X; de hecho debía ser un monasterio próspero gracias a las abundantes donaciones que recibió en esa centuria y al determinante papel que jugó en el proceso repoblador de la zona ${ }^{3}$. Su presencia ha sido constatada en la campaña de excavaciones llevada a cabo en 1982-83 y su vinculación con el fundador de la dinastía castellana se pone de manifiesto a través de dos donaciones, menos controvertidas que el documento fundacional, fechadas respectivamente en los años 931 y 937, además del dato inequívoco de haber elegido el cenobio como lugar de enterramiento ${ }^{4}$.

Varios documentos del siglo $\mathrm{X}$ citan el cenobio de San Pedro y San Pablo de

de un documento de donación otorgado al monasterio de Arlanza por Gonzalo Téllez y su esposa Flámula en la misma fecha de 12 de enero de 912, que sería la auténtica carta fundacional, y que ambos textos pudieron refundirse en uno solo, varios siglos después, con la intención de prestigiar la institución (J. PÉREZ DE URBel, El Condado de Castilla, vol. II, Madrid, 1970, p. 33). Aún así, la hipótesis plantea muchas cuestiones de carácter diplomático para que pueda ser admitida como válida (vid. A. LINAGE CONDE, Los orígenes del monacato benedictino en la Península Ibérica. II. La difusión de la "Regula Benedicti" en la Península Ibérica. III. "Monasticon Hispanum (398-1109)", León, 1973, vol. II, pp. 634-644).

${ }^{3}$ En el año 937 había ciento cincuenta monjes (M. C. LEÓN-SOTELO CASADO, "Formación y primera expansión del dominio monástico de San Pedro de Arlanza. Siglo X", En la España medieval. Estudios dedicados al profesor D. Julio González González, 1980, pp. 223-225).

${ }^{4}$ Las cuestiones referentes a las fuentes documentales y bibliográficas para el estudio de la iglesia románica de Arlanza se recogen en J. VALlejo BOzAL y M. D. TEIJEIRA PABlos, "Fuentes para el estudio de la iglesia del monasterio de San Pedro de Arlanza en los inicios del románico pleno en España", Boletín del Museo Arqueológico Nacional, vol. XIII, 1995, pp. 55-70. 
Arlanza con su iglesia ${ }^{5}$. Pero el gran problema que se ha planteado es si las primeras referencias se corresponden con el emplazamiento monástico actualmente en ruinas o con la iglesia llamada en el siglo XVII de San Pedro el Viejo o San Pelayo de Arlanza, edificio que se ha conocido siempre como ermita en relación con la fundación monástica y la población de época altomedieval. En efecto, presenta una construcción románica, asentada sobre otra edificación anterior, y reformada en el siglo $\mathrm{XVII}^{6}$.

Los primeros documentos conservados hablan de los Santos Apóstoles Pedro y Pablo, cuyas reliquias descansan escondidas y en cuyo honor se ha fundado una basílica junto a la villa de Lara, sobre un promontorio del río Arlanza. Algunos autores, basándose en los datos anteriores, proponen que la primera fundación monástica sería un colectivo de eremitas que tenían su centro de oración en la ermita y que el asentamiento del monasterio en el lugar actual no sería anterior al siglo XI. La expresión "super crepidinem" es la causa principal para situar esa primera basílica, dedicada a los santos Pedro y Pablo, en el lugar conocido como San Pedro el Viejo. La referencia al promontorio desaparece, en general, en escrituras del siglo XI, por lo que cabría pensar que entonces ya la iglesia del asentamiento monástico estaría ubicada junto al

-

${ }^{5}$ L. Serrano, Cartulario de San Pedro de Arlanza, Madrid, 1925.

${ }^{6}$ La historiografía y la secuencia arqueológica de este edificio se estudian en L. CABALLERO ZOREDA Y COLS., "La iglesia prerrománica de San Pedro el Viejo de Arlanza (Hortigüela, Burgos)", Numantia, nº 5, 1991, pp. 139-165 y L. CABAllero ZOREDA y L. CÁMARA, “Un caso de lecturas de paramentos y argumentación científica. San Pedro el Viejo de Arlanza. BurgosEspaña", Informes de la Construcción, 46 (1995), pp.7989. Las obras que se llevaron a cabo en los siglos XVII y XVIII quedan reflejadas en las visitas del 1-IV-1618 y 3-XI-1709 (Archivo Histórico Nacional. Sección de Clero, Leg. 1358, s/f). río, en el lugar en el que se encuentra actualmente. Sin embargo, aflora de nuevo en algún documento suscrito por Fernando I ${ }^{7}$. Esto indica que se trata de una fórmula que no tiene por qué ser interpretada en sentido literal y la desacredita como prueba para situar el cenobio del siglo $X$ en el lugar de la ermita ${ }^{8}$.

Tras la destruccción que supusieron las incursiones de Almanzor en la zona, el monasterio debió recuperarse con cierta rapidez, dando paso a un nuevo período de esplendor en el siglo XI, que junto con el XII fueron los de mayor apogeo para la comunidad. En estas dos centurias Arlanza gozó de la predilección por parte de algunos monarcas, especialmente Fernando I que tomó la decisión de enterrarse entre sus muros ${ }^{9}$; de la actividad de algunos abades relevantes, sobre todo en el ámbito religioso; del crecimiento del número de reliquias $\mathrm{y}$, con ellas, del prestigio del cenobio, y del aumento de las donaciones y de diversos beneficios jurisdiccionales ${ }^{10}$.

-

${ }^{7}$ L. SERRANO, Op.cit., doc. XXIV (29 de diciembre de 1041).

${ }^{8}$ El caso del monasterio de San Pedro de las Dueñas (León) puede servir como prueba fehaciente de que éste era un formulismo repetido sin sentido crítico en las escrituras de donación; concretamente en un documento de 1126 se señala: "Basilica fundata extat super crepidinem Alves qui dicitur Ceia secus stratam in quo loco permanet ecclesia miro honore fabricata...", cuando el solar en el que está ubicada tiene una cota muy similar a la del cercano río Cea. (Vid. J. M. FERnÁNDEZ CAtón, Catálogo del Archivo de San Pedro de las Dueñas, León, 1997, doc. 12).

${ }^{9}$ Todas las fuentes y los escritores eclesiásticos coinciden en señalar como especialmente significativa la ayuda y vinculación del monarca Fernando I con el monasterio. Sirvan como ejemplo A. DE YEPES, Op.cit., fols. 378v. y ss., y el Discurso anónimo (del Monasterio de San Pedro de Arlanza) sobre las reliquias de los santos Vicente, Sabina y Cristeta, Biblioteca Nacional, Ms. 8753, fol. 9 .

${ }^{10}$ M. C. LEÓN-SOTElo CASADO, “La expansión del dominio monástico de San Pedro de Arlanza a lo largo del siglo XI", En la España medieval. Estudios en memoria del profesor Don Salvador de Moxó, 1982, pp. 573-582. 
La pujanza del monasterio benedictino propició una reforma de las estructuras existentes para configurar un nuevo conjunto del que han persistido a lo largo de los siglos las ruinas del templo y de la sala capitular. Las dependencias monásticas del edificio románico debían extenderse hacia el Sureste, adecuándose a la disminución de las cotas de nivel del suelo a medida que se aproximaban hacia el río. Como únicos testigos de esas construcciones del siglo XII, se mantienen en pie dos portadas: una está embebida en el muro E. del claustro procesional barroco y la otra ha sido puesta al descubierto en las obras de restauración llevadas a cabo por el arquitecto Sancho Roda en el claustro menor, también denominado Claustro Nuevo, situado al oriente del anterior.

El nuevo templo se inició en el año 1080, en un momento en que la liturgia romana y el románico pleno se expandían por el Norte de la Península Ibérica. La datación exacta del inicio de las obras estaba indicada en un epígrafe situado en el ábside de la epístola. A pesar de que no se conserva la inscripción original, existe una reproducción de la misma, fechada en 1771, en el archivo del vecino monasterio de Santo Domingo de Silos: "ERA MCXVIII: SUMSIT INICIUM HANC OPERAM"111.

\footnotetext{
${ }^{11}$ Existe también una transcripción de la misma, realizada probablemente en 1770 (Colección de documentos copiados por el padre Francisco Méndez para el uso del Reverendo Padre Maestro Fray Enrique Flórez, Biblioteca Nacional, Ms. 1622, fol. 189r). R. AMADOR DE LOS Ríos, España. Sus monumentos y artes. Su naturaleza e Historia. Burgos, Barcelona, 1888, p. 907, fue el primero en publicar la noticia indicando el año 1081; sin embargo, M. FEROTIN, Histoire de l'Abbaye de Silos, París, 1897, p. 11, reprodujo la copia de Silos, en la que se puede leer correctamente la era 1118, es decir, el año 1080 como fecha de inicio de las obras. J. VAllejo Bozal y M. D. TEIJEIRA PABLOS, Op.cit., p. 66, han estudiado los caracteres de la inscripción y han concluido que se trataba de un epígrafe contemporáneo de las obras que notifica.
}

A lo largo de los siglos X y XI la abadía había recibido copiosas donaciones que incrementaron sus rentas y animaron al abad Vicente (1073-1099) y a sus monjes a emprender la construcción de un templo adecuado, por un lado, a la nueva liturgia que sustituiría al viejo rito hispano y en cuya implantación la orden benedictina jugó un papel primordial, y, por otra parte, a las características de los grandes templos que por entonces se construían en los reinos de la España cristiana, especialmente a lo largo del Camino de Santiago, como las catedrales de Santiago de Compostela y Jaca, las iglesias de San Isidoro de León y Frómista y los monasterios benedictinos de Sahagún y Santo Domingo de Silos.

De acuerdo a esas nuevas corrientes del románico pleno que llegaban del otro lado de los Pirineos, la iglesia de Arlanza se concibió con planta basilical de tres naves, divididas en cuatro tramos, sin transepto señalado y con una cabecera compuesta por tres ábsides semicirculares precedidos por sendos tramos rectos, el central más ancho y profundo que los laterales (Figura 1).

El acceso a los espacios absidales se hace a través de arcos apeados en columnas pareadas, un tipo de soporte que se encuentra, aunque con distinta ubicación, en San Pedro de Teverga, San Martín de Frómista y la iglesia alta de Silos. El aspecto más peculiar de estos apeos es la interrupción de los fustes geminados a cierta altura del muro de los ábsides laterales, para ser sustituidos por una sola columna de mayor diámetro, circunstancia que debe relacionarse con un cambio de etapa constructiva en la que se elevó la altura de muros prevista inicialmente.

Las arquerías de separación de naves se elevaban sobre pilares cruciformes con semicolumnas adosadas a los cuatro frentes que soportaban arcos doblados. Los elevados plintos circulares que sirven de base a 
los pilares son otro de los elementos característicos de la arquitectura de fines del siglo XI y comienzos del XII, como podemos ver, por ejemplo, en la iglesia de San Isidoro, en la de San Pedro de las Dueñas o en la cabecera de la de San Benito de Sahagún, todas ellas en la provincia de León.

Los capiteles presentan decoración de hojas con apomados o piñas y animales afrontados, generalmente cuadrúpedos o aves. La talla es bastante torpe en el ábside central y más rica en los laterales, lo que también puede apreciarse en los diferentes cimacios y líneas de imposta, compuestos por elementos vegetales en arabesco, entrelazos y por el característico ajedrezado.

Al exterior, los ábsides presentan columnas adosadas mientras que en los muros de las naves se utilizó un tipo peculiar de contrafuerte con columna adosada, prolongado hasta la cornisa, en la que aparece la característica decoración de taqueado en tres filas. Por debajo, el diseño de arquillos ciegos rememora la arquitectura del primer románico. Estos motivos de ascendencia lombarda son muy poco frecuentes en la arquitectura hispana posterior a mediados del siglo XI y menos aún en Castilla; sin embargo, se repiten en la iglesia más tardía de San Lorenzo de Vallejo de Mena y, en otro contexto, se encuentran en la de Santa María de Urueña (Valladolid).

Sobre el tipo de cubiertas es difícil afirmar nada, pues son muy escasos los restos que han llegado hasta la actualidad y pertenecen únicamente a la zona de la cabecera. Se puede presumir tanto que la nave central y las laterales se cerraron con bóvedas de cañón reforzadas con arcos fajones como que pudieron carecer de cualquier tipo de abovedamiento ${ }^{12}$. Tampoco

\footnotetext{
${ }^{12}$ La primera hipótesis es la que defendió Whitehill a partir de la comparación con la iglesia de Frómista, que presenta el mismo tipo de soportes (W. M.
}

resulta fácil determinar si el transepto estaba o no realzado en altura. Vallejo y Teijeira, basándose en los vestigios de cubiertas que aún se observan en la parte septentrional de la iglesia, sobre el muro Sur de la torre, apuntan como conclusión más plausible que las cubiertas del templo románico consistiesen en una simple armadura de madera ${ }^{13}$. Aún cuando el edificio se hubiese concebido estructuralmente para ser abovedado, tal vez se cerró, en diversas ocasiones, con techumbres provisionales hasta que, a fines del siglo XV y comienzos del XVI se obtuvieron los medios económicos necesarios para hacer el cerramiento pétreo, al tiempo que se aumentó la altura del ábside central y se elevó un cimborrio sobre el crucero $^{14}$.

\section{RECONSTRUCCIÓN DEL CUERPO OCCIDENTAL}

A los pies de la iglesia, adosada al muro occidental y comunicada con ella mediante un vano, hay una cámara de planta rectangular con acceso desde el exterior por el lado Norte. Las distintas obras de acondicionamiento que se han llevado a cabo a lo largo de los siglos han modificado

WHITEHILL, Spanish romanesque architecture of the eleventh century, Oxford, 1941, pp. 203-204). M. GÓMEZ MORENO, El arte románico en España. Esquema de un libro, Madrid, 1934, p. 94, J. GUDIOL y J. A. GAYA, Arquitectura y escultura románicas, "Ars Hispaniae", vol. V, Madrid, 1948, p. 233, y J. A. GAYA NUÑO, La arquitectura española en sus monumentos desaparecidos, Madrid, 1961, p. 123, plantean que, de haber existido algún tipo de bóveda, podía haber sido de cañón corrido al estilo poitevino, pero el primero de ellos se inclina por la ausencia de abovedamiento.

13 J. Vallejo Bozal y M. D. Teijeira Pablos, Op.cit., pp. 67-68.

${ }^{14}$ Sobre la reforma tardogótica de la cabecera de la iglesia y la construcción del cimborrio han publicado recientemente M. A. FRANCO MATA, J. MERINO DE CÁCERES Y M. SOBRINO, "Elementos arquitectónicos tardogóticos de la iglesia del monasterio de Arlanza (Burgos) en el Museo Arqueológico Nacional", Boletín del Museo Arqueológico Nacional, 19 (2001), pp.153-169. 
la fisonomía y la fábrica original de esta estancia que, en la actualidad, se encuentra recorrida por las escaleras que descienden desde el Norte y se prolongan en su interior con un giro hacia oriente para facilitar el acceso de los fieles al templo. A pesar de todas las modificaciones, ese vestíbulo que precede al templo arlantino aún se puede reconocer como un ejemplo del tipo de dependencias alineadas con el eje longitudinal de la iglesia que corresponden habitualmente a espacios de carácter funerario, con larga tradición en la arquitectura medieval hispana. En el caso de Arlanza, la ausencia de fuentes documentales y el carácter legendario de las crónicas dificultan efectuar precisiones sobre su cronología y funcionalidad ${ }^{15}$.

a) Fases I y II: etapa prerrománica y románica

La estancia, que hoy es un espacio rectangular, de 4,32 x 6,55 m., parece haber sido construida antes que la iglesia románica, al menos antes que el cerramiento occidental de sus naves, que afectó a esta estructura. Existen razones de planteamiento constructivo que avalan esta teoría (Figura 2 a):

a) La diferencia de grosor que presentan los dos paramentos que la cierran hacia el Este indica que el encuentro entre la iglesia y la cámara se ha producido sin planificación previa.

\footnotetext{
15 I. BANGO TORVISO, “El espacio para enterramientos privilegiados en la arquitectura medieval española", Anuario del Departamento de Historia y Teoría del Arte, vol IV, 1992, pp. 93-132, lo insinúa, aunque no lo cite, al incluir las figs. 17, con el plano de la iglesia publicado por M. Gómez Moreno, y 18, con la reconstrucción hipotética de los volúmenes de la iglesia y la cámara occidental; J. L. SENRA, "Aproximación a los espacios litúrgicos-funerarios en Castilla y León: pórticos y galileas", Gesta, XXXVI/2, 1997, pp. 122-144, no cita el caso de Arlanza.
}

b) El eje axial de la cámara se halla descentrado con respecto al templo, luego su construcción no fue proyectada al tiempo ni con posterioridad al mismo. De haber sido así, hubiera estado perfectamente alineada con al eje longitudinal del mismo, aspecto que se observa en los esquemas realizados por Gómez Moreno y Bango Torviso pero que no responde a la realidad planimétrica del edificio ${ }^{16}$.

La irregularidad que se observa en el trazado podría achacarse a modificaciones posteriores, como la introducción de la escalera hasta la puerta del templo; sin embargo, nunca pudo haberse extendido más hacia el Norte debido al subsuelo rocoso que aflora en esa zona.

Fernando I, gran benefactor del monasterio, había manifestado en 1039 su deseo de enterrarse en Arlanza ${ }^{17}$. Siguiendo una larga tradición de la monarquía asturleonesa, según la cual los reyes, cuyos restos mortales aún no podían introducirse en el interior de los templos, construyeron sus panteones lo más próximos a ellos, situados especialmente a los pies de la iglesia, es posible que en el monasterio de los Santos Pedro y Pablo se levantara un recinto funerario adecuado para contener el sepulcro del monarca ${ }^{18}$. Si atendemos a la ubicación y estructura del Panteón de San Isidoro de León, que se construyó con esa misma finalidad una vez que Fernando I cambió de

\footnotetext{
${ }^{16}$ M. GÓMEZ MORENO, Op.cit., p. 95; I. BANGO TORVISO, Op.cit., fig. 18.

${ }^{17}$ L. SERRANO, Op.cit., doc. XXXII.

${ }^{18}$ Respecto a este tema pueden consultarse, entre otros, I. BANGO TORVISO, Op.cit., pp. 93-132, y “La vieja liturgia hispánica y la interpretación funcional del templo prerrománico", en VII Semana de Estudios Medievales, La Rioja, 1997, pp. 61-120, especialmente, 7982; C. ABAD CASTRO, "Espacios y capillas funerarias de carácter real" y M. VALDÉS FERNÁNDEZ, "El Panteón real de la Colegiata de San Isidoro de León", en Maravillas de la España medieval. Tesoro sagrado y monarquía, Madrid, 2001, pp. 63-72 y 73-84, respectivamente.
} 
planes, tal vez influenciado por los deseos de su esposa doña Sancha, no parece descabellado pensar que en el monasterio arlantino existiera una cámara funeraria con esa misma ubicación respecto a la iglesia entonces existente, es decir, la basílica prerrománica.

Si la vinculación de Fernando I con la cámara occidental de Arlanza no es más que una hipótesis, muy poco probable debido a la temprana decisión de reposar eternamente en San Isidoro de León y a la modestia del panteón burgalés, lo que parece probado es que en este lugar estuvo el sepulcro de Fernán González. Son frecuentes los casos de cámaras funerarias, tanto regias como nobiliarias destinadas a dar sepultura a los benefactores de distintas iglesias y monasterios, situadas en ese mismo lugar ${ }^{19}$.

La primera ubicación de los cadáveres del conde y su esposa es desconocida. Sobre el momento de su traslado al interior de la iglesia existen razonables dudas, pero debió suceder en el orden y momento que señala Huidobro, ya que se basa en el manuscrito de fray Juan de Pereda y éste, a su vez, en los datos del archivo de la abadía ${ }^{20}$. Según estos datos, el 30 de junio de 1274, por orden del abad don Domingo, los restos de Fernán González se trasladaron al interior de la iglesia y se colocaron en el centro. En 1369, debido a que estorbaban en la celebración de los oficios divinos, el abad

${ }^{19}$ J. L. SENRA, Op.cit., pp. 122-144, se ocupa de los espacios occidentales de las iglesias monásticas benedictinas de Sahagún, Carrión de los Condes y San Isidoro de Dueñas, todos ellos construidos en el siglo XI.

${ }^{20}$ Los datos que aportaba el desaparecido manuscrito, redactado en 1563 por un monje de Arlanza, únicamente pueden conocerse a través de las publicaciones de L. HUIDOBRO, "El monasterio de San Pedro de Arlanza y su primer Compendio historial, inédito. I", Boletín de la Comisión Provincial de Monumentos Históricos y Artísticos de Burgos, 1922, pp. 199-207, y II, 1927, pp. 211-214. don Andrés mandó que se pusieran en el lado del evangelio, con un epígrafe sobre el muro en donde quedase constancia de lo sucedido $^{21}$. De esta inscripción no ha quedado ningún testimonio; ni siquiera se menciona el sepulcro del conde en el esquemático plano de la iglesia sobre el que Pereda señaló la ubicación de lápidas y reliquias, lo que resulta sorprendente dada su relevancia ${ }^{22}$.

El Poema de Fernán González, redactado por un monje del monasterio ca. 12501252, pone en boca del conde la siguiente promesa: "Faré otra iglesia de más fuerte çimiento/ faré dentro en ella el mi soterramiento/ dare í donde vivan de monjes más de çientol sirvan todos a Dios, fagan su mandamiento" ${ }^{\prime 23}$. La Crónica escrita por el abad don Gonzalo de Arredondo en 1515 afirma que el fundador del condado de Castilla había escogido el monasterio "para depositar su cuerpo hasta el fin del mundo" $\mathrm{y}$, por cumplir su voluntad, a su muerte fue trasladado el cadáver a Arlanza y pusieron su sepulcro, que era de mármol, "en fin de la iglesia por repudio de los mundanales" y que "colocaron su ynsignia y

\footnotetext{
${ }^{21}$ Plantea contradicciones con respecto a alguna de las afirmaciones realizadas por autores anteriores. Así, Yepes dice que permaneció más de quinientos años fuera, en el atrio, hasta que fue trasladado al interior. A este respecto advierte el padre Flórez que "le metieron en la capilla mayor, en el crucero, donde yace con la condesa doña Sancha" (A. DE YEPES, Crónica de la Orden de San Benito, t. I, p. 378; E. FLÓREZ, Op.cit., vol. XXVII, pp. 49-50).

${ }^{22}$ La aportación de Huidobro puede tomarse en muchos casos con reservas porque se confunden los datos que puedan estar sacados del manuscrito de Pereda con sus juicios de valor personales, porque no hay posibilidad de cotejarlos con el texto original e, incluso, porque desconocemos el grado de fiabilidad del propio manuscrito. En el caso de la planta de la iglesia, advierte que reproduce el dibujo original de Pereda. L. HUIDOBRO, Op.cit. I, p. 205.

${ }^{23}$ Poema de Fernán González, estr. 248, ed. de H. Salvador Martínez, Madrid, 1991.
} 
pendon y sus armas conjunto con la sepultura, a donde oy dia estan" ${ }^{\prime 24}$.

Para evitar la contradicción entre las palabras del Poema -de las que se hace eco Arredondo- y los cánones del concilio bracarense que prohibían la inhumación en el interior de los templos, aún vigentes cuando falleció Fernán González, Amador de los Ríos planteó la posibilidad de que la sepultura hubiera sido conducida desde el atrio a la iglesia en la primera mitad del siglo XIII, momento en que ya se permitía el enterramiento de legos en el interior; cuando, unas décadas más tarde, se redactó el Poema de Fernán González, se habría perdido la memoria de la primera ubicación y el monje poeta lo sitúa desde los orígenes a los pies del templo ${ }^{25}$.

Ese lugar, "en fin de la iglesia", en donde se localiza inicialmente el sepulcro, puede identificarse con el pórtico occidental, de modo que la versión del Poema y la Crónica no se contradicen con la de Pereda, a través de Huidobro, según la cual el traslado -entendemos desde la cámara funeraria hasta el crucero del templo- se produjo unos años más tarde, en 1274.

Desde que la catedral de Santiago de Compostela se convirtió en panteón real con los sepulcros de Fernando II y Alfonso IX, los cuerpos de los reyes empezaron a situarse en el interior de los templos, entre otras cosas para aumentar su prestigio y también por razones litúrgicas, pero ante la capilla mayor o cerca de ella. Así ocurrió en Sahagún, en Las Huelgas y en otros lugares en fechas próximas a las citadas para Ar-

\footnotetext{
24 G. DE ARREDONDO, Chronica del Bienaventurado Catholico Caballero el conde Fernán Gonçalez, 1622, Ms. De la Biblioteca Nacional, fol. 264.

${ }^{25}$ R. AMADOR DE LOS Ríos, Las ruinas del monasterio de Arlanza en la provincia de Burgos. Estudio históricoarqueológico, Madrid, 1896, p. 7, nota 2.
}

lanza ${ }^{26}$. Muy pronto comenzaron a introducirse las sepulturas de dignidades eclesiásticas e, incluso, las de otras personalidades de alto estrato social directamente vinculadas con la historia de la institución religiosa correspondiente.

En el caso de Fernán González, las fuentes literarias y los testimonios arquitectónicos inducen a pensar que la sepultura estaba en un espacio especialmente construido para ello a los pies de la iglesia prerrománica, bien desde el momento de su muerte en el siglo $X$, bien cuando sus restos fueron trasladados desde San Pedro el Viejo, si es cierto que en un principio estuvieron allí. La expresión "en fin de la iglesia", utilizada por el autor del Poema y por don Gonzalo de Arredondo, debe referirse a ese lugar y no al interior del templo.

Como era frecuente en la tradición hispana, el espacio funerario, en principio, tendría acceso únicamente desde la iglesia $\mathrm{y}$, posteriormente, pudo abrirse al exterior para facilitar la entrada a los peregrinos y fieles que participaban en los actos litúrgicos del monasterio. Esta circunstancia, que se repitió en otros casos, como Sahagún, era casi obligada en la iglesia románica de Arlanza, en donde el nivel exterior del terreno alcanzaba prácticamente la mitad de la altura del muro Norte, impidiendo la apertura de una puerta (Figura 3 a). Además, el manuscrito de fray Juan de Pereda hablaba de la existencia de un recinto fortificado que englobaría las dependencias monásticas, con una serie de torres que fueron sucesivamente suprimidas. La ubicación de las torres de defensa por el lado septentrio-

\footnotetext{
${ }^{26}$ M. V. HERRÁEZ y COLS, Esplendor y decadencia de un monasterio medieval. El patrimonio artístico de San Benito de Sahagún, León, 2000, pp. 137-141; R. SÁNCHEZ AMEIJEIRAS, "El "çementerio real" de Alfonso VIII en Las Huelgas de Burgos", Semata, no 10, 1998, pp. 77109; F. GUTIÉRREZ BAÑOS, Las empresas artísticas de Sancho IV el Bravo, Burgos, 1997, pp. 152-163.
} 
nal y occidental del cenobio indica que la cerca seguía la línea del propio templo, y así se mantuvo hasta que fueron derribadas la de fray Pelayo y la de doña Sancha a finales del siglo $\mathrm{XV}^{27}$. Por tanto, no parece probable que se abriera un gran vano de acceso en ese lado durante el período medieval.

La portada románica que se encontraba aún a finales del siglo XIX en el lado Norte de la cámara, fue llevada en 1895 al Museo Arqueológico Nacional, a instancias de Rodrigo Amador ${ }^{28}$. La obra, sin embargo, no se trasladó completa, ya que el dintel, decorado en su centro con una cruz griega patada, y el tímpano liso no gozaron de la misma protección.

Su aspecto "in situ" se puede apreciar a través de fotografías antiguas en las que, por otra parte, se advierte la cantidad de escombro acumulado ante ella. La portada es de medio punto abocinada, con varias arquivoltas decoradas con simples molduras -fundamentalmente boceles, alguno de ellos sogueado- y motivos ornamentales, como bolas y grecas a base de elementos geométricos o vegetales estilizados, que reproducen los mismos modelos con los que se ornan las líneas de imposta de los ábsides del templo. El arco apea sobre jambas con dos pares de columnas acodilladas, de fuste acanalado las internas y sogueado las externas, y capiteles similares en las cuatro: corintios estilizados con hojas y apomados, muy parecidos en su decoración a algunos de los que se conservan hoy en la sacristía procedentes de la iglesia y del

\footnotetext{
${ }^{27}$ L. HuidoBro, Op.cit. II, pp. 211-214. Habla en concreto de la existencia de las torres del Capítulo y el Conde, en la fachada principal -derribadas cuando se hizo la nueva entrada-, la del Tesoro -única conservada-, la de Fray Pelayo -donde posteriormente se ubicaría el coro- y la de Doña Sancha -al Sur, donde después estaría el refectorio-.

${ }^{28}$ Museo Arqueológico Nacional. № de inventario 207, expediente 1895/11
}

claustro románico. En origen el paramento parecía estar rematado por una cornisa decorada con bolas, similares a las ya descritas de las arquivoltas, que pudieran pertenecer a la reforma tardogótica que sufrió la iglesia entre los siglos XV y XVI (Figura 4).

El conjunto de la portada resulta de sorprendente belleza, dentro de la sobriedad y parquedad de sus elementos ornamentales, debido a la gran delicadeza y muy buen oficio que demuestra el escultor (Figura 5). Estilísticamente puede enlazar con las obras románicas más tardías del templo, en las que la talla y el refinamiento decorativo alcanzan cotas más elevadas, como la parte alta de los ábsides laterales o, incluso, con los restos del claustro tardorrománico, entre los que se encuentra el llamado "sepulcro de Mudarra"29. Por otro lado, sus dimensiones son excesivas para la anchura del muro en el que se encontraba, totalmente encajonado entre la estructura del templo y el desnivel del terreno, hasta el punto de que lo ocupaba totalmente y aún quedaban fracturadas las arquivoltas exteriores por el lado oriental, detalle que se advierte en las imágenes y que anota Amador de los Ríos ${ }^{30}$.

Todo ello hace suponer que la portada se talló en el siglo XII para un lugar diferente, probablemente uno de los dos accesos desde el claustro a la iglesia por su muro meridional. Su ubicación como entrada Norte pudo tener lugar en relación con la monumentalización a la que fue sometido este acceso en la Edad Moderna, tal vez coincidiendo con la reforma barroca del

\footnotetext{
${ }^{29}$ Sobre este sepulcro y su datación, vid. J. L. SENRA, "La escultura románica y sus problemas de interpretación: el llamado sepulcro "de Mudarra" procedente de San Pedro de Arlanza", Archivo Español de Arte, 285, 1999, pp. 25-38.

${ }^{30}$ R. AMADOR DE LOS RÍOS, Op.cit.
} 
claustro y la colocación en él de una portada acorde al nuevo lenguaje artístico.

\section{b) Fase III: etapa tardogótica.}

A fines del siglo XV se abrió un breve período de crecimiento de las fuentes de financiación del monasterio arlantino, lo que en coincidencia con la presencia de importantes figuras al frente del abadengo del mismo favoreció la realización de diversas reformas en el edificio. La actividad constructiva debió iniciarse durante la etapa en la que Diego de la Parra fue abad del monasterio (1481-1505). Este abad parece haber encargado a Juan de Colonia, en 1482, una reforma de gran magnitud que afectaría fundamentalmente a la iglesia, donde se renovarían todas las cubiertas y se realizaría la elevada linterna sobre el crucero. ${ }^{31}$ Estas obras, que a la muerte del citado abad continuaría su sucesor, Gonzalo de Arredondo, y que contaron además con la participación de Simón y Francisco de Colonia, ${ }^{32}$ y con la ayuda económica del duque de Osuna, ${ }^{33}$ supondrían también la intervención en la zona occidental del monasterio con la realización de un nuevo refectorio $\mathrm{y}$, fundamentalmente, la modificación completa del extremo occidental de la iglesia. En esta zona se encontraba la cámara anteriormente mencionada, cerca de la cual se habría construido durante el siglo XI o XII la torre de Fray Pelayo, la cerca de cerramiento y el camino de subida a la ermita de San Pedro el Viejo. La reforma de esta zona tuvo como consecuencia la

\footnotetext{
${ }^{31}$ Sobre esta última obra cfr. A. FRANCO MATA, J. MERINO DE CÁCERES y M. SOBRINO GONZÁLEZ, Op.cit.

${ }^{32}$ En la iglesia podía verse, en el muro del lado de la epístola, la inscripción "Ximón de Colonia me fecit, anno de 1507" y en la linterna "Francisco de Colonia me construyó, anno de 1525". Ambas aparecen recogidas en L. HUIDOBRO, Op.cit., II , p. 213.

${ }^{33}$ M. MARTínEZ Burgos, "En torno a la catedral de Burgos. II. Colonias y Siloés", Boletín de la Institución Fernán González, 1954-1955, p. 555.
}

demolición de la torre y de la cerca y la modificación del trazado del camino, que se movió unos metros más allá, en alto, hasta donde discurre en la actualidad (Figura 6). ${ }^{34}$

La intervención en la cámara occidental llevada a cabo a principios del siglo XVI supuso el alargamiento de la planta de la iglesia con la construcción de un nuevo coro, colocado en alto gracias a la posibilidad de aprovechar la estancia citada, que para estas fechas hacía ya tiempo que habría perdido su función funeraria, y el desnivel que el terreno presentaba en esta zona (Figura 7). No se conoce la causa directa que llevó a plantear este nuevo espacio. Es probable que desde algún tiempo atrás el templo viviera una etapa de mayor apertura hacia el exterior, bien porque adoptase funciones parroquiales, que se sabe que cumplió al menos desde época moderna, bien porque la importancia de las reliquias que conservaba generase un relevante movimiento peregrinatorio. ${ }^{35}$ Es probable que la iglesia registrase un flujo más o menos continuo de gente que molestase a los monjes, hasta entonces recogidos en el coro antiguo que estaría en el interior de la iglesia, probablemente ubicado en la nave mayor, cerca del altar principal y de las reliquias más buscadas por los peregrinos. Si se une a este posible problema la conso-

-

${ }^{34}$ L. HUIDOBRO, Op.cit., p. 212

${ }^{35}$ La documentación conservada del monasterio habla repetidamente de la bien ganada fama que el cenobio tuvo, durante toda su historia, por el número e importancia de las reliquias que conservaba, algunas de las cuales, sobre todo las vinculadas a la memoria de Fernán González -su cuerpo, trasladado en época gótica al interior de la iglesia, la cruz que llevaba en la batalla, la Virgen de las Batallas, su anillo- fueron objeto de una importante devoción, probablemente muy potenciada por el propio monasterio. Ver como ejemplos los casos recogidos en Archivo Histórico Provincial de Burgos. Protocolos Notariales. C.1914 y Archivo Histórico Nacional. Sección de Clero. Leg.1358. Visitas del Real Monasterio de San Pedro de Arlanza hechas por los reverendísimos padres de la religión de San Benito. 1614-1719. 
lidación en este período de una tendencia que llevaba a colocar los coros a los pies de los templos, en alto sobre la puerta occidental, liberando así el espacio de la iglesia, ${ }^{36}$ se obtiene una explicación bastante lógica para la construcción de este nuevo espacio, favorecida además por una situación económica más o menos airosa tras un período importante de crisis, y por la presencia en el monasterio de artistas de la talla de Juan, Simón o Francisco de Colonia.

La reforma del cuerpo occidental supondría la ampliación de la estructura anterior, manteniendo su anchura, pero haciéndola más larga y alta. Para ello, aprovechando el desnivel del terreno, que comienza a subir en esta zona, y partiendo de los muros de la cámara primigenia en la parte baja, se levantarían, una vez eliminada la cubierta anterior, los lienzos meridional, occidental y septentrional, quedando el lado oriental abierto al templo para poder seguir la celebración de los servicios religiosos desde el coro. Esta continuidad espacial de la cámara con respecto del templo se conseguiría gracias a la sobrelevación de los muros mencionados hasta alcanzar la misma altura que la cubierta de la nave central, transepto y ábside principal del templo, lo que por otra parte supuso la enfatización simbólica de la importancia de este espacio, asimilado a los más relevantes del conjunto templario (Figura $3 \mathrm{~b}$ ).

En el interior se organizaría en dos pisos, uno bajo, que supondría la reutilización del espacio original de la cámara como único acceso al templo desde el exterior del monasterio, y uno alto que correspondería a un coro elevado apoyado por su lado occidental en la propia roca que aflora en esta zona en altura y por su lado oriental en

\footnotetext{
${ }^{36}$ En el Monasterio benedictino de Sahagún también se construyó en el siglo XV el coro alto a los pies de la iglesia, sobre el cuerpo que había sido panteón real. M. V. HeRráEZ y COLS., Op.cit., pp.162 y 163.
}

un probable alfarje volado sobre la cámara primitiva. Bajo una bóveda de terceletes, de la que restan únicamente el arranque de los nervios apoyados sobre sendas ménsulas en la confluencia del muro occidental con los septentrional y meridional, e iluminado directamente a través del gran óculo occidental, se encontraría el coro de monjes, formado por una sillería lígnea no demasiado grande, ${ }^{37}$ a la que se accedería directamente desde la sala adyacente a través de una puerta, aún hoy visible, en el muro meridional (Figuras 2 b y 7 ).

c) Fase IV: reformas de la Edad Moderna (ss. XVII y XVIII)

Los siglos XVII y XVIII, especialmente el primero, fueron para el monasterio arlantino un período de continua actividad constructiva a pesar de que la situación financiera de la comunidad debía ser francamente mala. A la necesidad de unirse a la corriente generalizada de reforma de los claustros benedictinos, iniciada ya en el siglo XVI, debió sumarse un muy avanzado estado de deterioro de los principales espacios monásticos. Así se llevaron a cabo la construcción de ambos claustros y la inmensa mayoría de las estancias en torno a ellos, además de realizar reformas de diversa importancia en los espacios que se mantuvieron, principalmente la sacristía y la antigua sala capitular. ${ }^{38}$

\footnotetext{
${ }^{37}$ En el anuncio de la primera subasta del edificio monasterial tras la supresión de la comunidad durante el período desamortizador de Mendizábal, se cita la sillería entre los bienes muebles que aún permanecían en la iglesia: “...en el coro existen 26 sillas de nogal”. Boletín Oficial de la Provincia de Burgos, no 979 de 7 de junio de 1844.

${ }^{38}$ E. Carrero Santamaría y V. González De CASTRO, "Arquitectura clasicista en Burgos: noticias documentales de la obra de Pedro Díaz de Palacios en San Pedro de Arlanza (1629-1659)", Anuario del Departamento de Historia y Teoría del Arte, V (1993), pp.111119. Archivo Histórico Nacional. Sección de Clero. Leg.cit.
} 
Si bien apenas se conservan datos sobre la realización de obras en la zona occidental de la iglesia, con la excepción de una nueva escalera de subida al coro, ${ }^{39}$ es evidente que toda esta zona fue modificada con posterioridad a la fase tardogótica, por lo que lo más probable es que estas reformas se hicieran coincidiendo con la realización de otras tareas constructivas dentro del monasterio. Las obras de reforma supondrían la mejora de la comunicación entre este cuerpo occidental y la iglesia, probablemente con el objetivo de facilitar y dignificar el acceso al templo desde el exterior del monasterio. Para ello se habilitaron una serie de nuevos elementos arquitectónicos.

En primer lugar se llevaría a cabo una regularización del acceso al templo desde la cámara occidental. Para ello se colocaron sendas jambas, que marcan una puerta de trazado abocinado, abierto hacia la cámara, que junto con la gran escalera semicircular levantada en los primeros metros de la nave central crean un acceso claramente monumentalizado, de cuyo aspecto original dan solamente una ligera idea los restos hoy conservados, que se limitan a su parte inferior (Figuras 2c y 8).

En segundo lugar se procedería a la reforma de la parte septentrional con el fin de facilitar y monumentalizar el acceso a la iglesia desde el exterior del monasterio, a través de la cámara occidental. Para ello debió arreglarse la escalera que salvaba el desnivel entre el vano abierto en la cerca, por el que penetrarían los fieles desde el exterior del cenobio, y el cuerpo occidental, y su correspondiente pavimento pétreo, que puede verse hoy aunque en un estado de deterioro bastante avanzado debido a

\footnotetext{
${ }^{39}$ En 1618 se tomaron sendos acuerdos para realizar una escalera en la capilla donde anteriormente se encontraba la sala capitular, para facilitar la subida al claustro, y otra "...por donde se ha de subir al choro y bajar al refitorio...". Archivo Histórico Nacional. Leg.cit.
}

que esta zona estuvo cubierta por escombros y maleza durante mucho tiempo. En relación con esta obra es posible que se colocase la puerta hoy conservada en el Museo Arqueológico Nacional, que se abrió en el muro septentrional de la cámara hasta su traslado a fines del siglo XIX. Dicha puerta habría constituido tradicionalmente el acceso principal del templo, pero únicamente para los religiosos por lo que debió haber estado colocada originalmente en el muro meridional del mismo. Probablemente la construcción de la puerta monumental que hoy se encuentra en el Monasterio de San Juan de Burgos y que originalmente se encontraba en el extremo suroccidental de la iglesia, abierta al claustro procesional, permitiera la reutilización de la puerta románica que pudo haber estado hasta entonces en dicho acceso. El incremento de las funciones parroquiales del templo, con el consiguiente flujo de fieles que debía acceder al mismo desde la cerca septentrional, motivaría no sólo la mejora de la escalera anteriormente mencionada, sino también la monumentalización de la que sería desde entonces puerta habitual de la iglesia (Figura 9).

Paralelamente debieron llevarse a cabo otras obras de escaso valor artístico aunque imprescindibles para el acondicionamiento de toda esta zona. Así, lo irregular del terreno en la zona noroccidental del monasterio, con una brusca elevación de varios metros, hacía imprescindible la construcción de los correspondientes muros de contención y cerramiento. Se sabe que en 1647 el monasterio contrató a Juan Otero, Domingo del Regato, Pedro de la Herrería y Francisco de Isla para hacer las cercas del lado meridional del cenobio. ${ }^{40}$ Es probable que por esas mismas fechas se llevaran a cabo nuevas reformas de la cerca ya exis-

\footnotetext{
${ }^{40}$ Archivo Histórico Provincial de Burgos. Protocolos Notariales. C.1914. Fols.172r.-173v.
} 
tente en la parte noroccidental y del cerramiento que existía en esta zona desde el período románico y que se había visto afectado por la reforma del cuerpo occidental del templo en el siglo XVI. Del mismo modo se realizaría el muro de contención, del que debe destacarse la presencia de un pequeño lienzo adosado, rematado en una línea diagonal descendente, con probable función de pasamanos, coincidiendo con los últimos escalones de la escalera de bajada a la cámara (Figura 9).

Finalmente quedan algunos restos ornamentales de la reforma moderna en el interior de la cámara. El primero es un pequeño hueco pétreo rematado en bóveda de horno y abierto en el muro meridional, que pudo haber realizado funciones bien de hornacina, bien de pila de agua bendita, probablemente en relación con el uso parroquial que el templo de Arlanza llevó a cabo durante esta época. También se observan restos, hoy muy fragmentarios, del tratamiento de los muros interiores de esta estancia, cuyo avanzado estado de deterioro impide sostener cualquier hipótesis, aunque parece haber sido un simple encalado del muro que ocultaría la tosquedad de su fábrica al interior (Figura 10).

\section{DESCRIPCIÓN DE ELEMENTOS} (Figura 2)

La arqueología de la arquitectura ofrece la posibilidad de leer minuciosamente los paramentos removidos que arrojan datos diversos, por lo que su uso es muy interesante en trabajos destinados a orientar una intervención arquitectónica. Pero supone una tarea ardua, sobre todo por la necesidad de obtener imágenes exactas y detalladas de cada una de las zonas objeto de estudio.

Tras haber determinado las distintas fases histórico-artísticas del cuerpo occidental del templo arlantino, creemos que una lectura más detallada de sus elementos puede aportar claridad a la historia constructiva. Se pueden diferenciar elementos que quedan registrados en el cuadro adjunto $y$ que corresponden a las cuatro fases $\mathrm{o}$ periodos artísticos definidos anteriormente.

1.- El muro Sur, que aparece revocado, es el único elemento del espacio que servía como ingreso a la iglesia desde el exterior del monasterio que podría mantener la fábrica primitiva, anterior al cerramiento de los pies del templo (Figuras $2 \mathrm{~b}$ y 9).

2 y 3.- Los tramos de muro situados a ambos lados de las jambas del vano que sirve de acceso al templo desde los pies presentan fábrica de sillares de piedra caliza colocados a soga con relleno de ripio, salvo en la parte inferior del lienzo Norte en donde aflora la roca viva sobre la que se cimentó tanto el muro como el pilar correspondiente, cuyo plinto se sitúa a una cota más alta que el de su homólogo del lado Sur (Figuras 7 y 9).

4 y 5.- Los pilares y columnas adosadas que soportaban el último arco de las arquerías de separación de naves serían levantados en el siglo XII, cuando la construcción del templo llegó a los pies. Forman unidad con los elementos 2 y 3 (Figura 7).

6.- El elemento número 6 constituiría el límite meridional del coro alto. Se trata de un muro de mampostería de cantera, concertada y bien trabada que apoyaría directamente sobre el elemento número 1. La escasa calidad de su aparejo se compensaría en origen con la utilización, al interior, de un enlucido, cuyos restos se estudiarán en el número 21 y al exterior de una hoja de sillería isódoma, probablemente a soga, sistema visible en otras partes del monasterio, entre ellas el elemento número 8 , que sería coetáneo en su construcción. El muro se conserva sólo parcialmente, ya que ha perdido no sólo el enlace con la cubierta en 
su parte superior, sino también todo el extremo oriental, lo que ha favorecido la destrucción de la zona alta del elemento número 1. Sobre su superficie se conservan los elementos 13 y 15, que se comentarán posteriormente y que suponen los restos de algunos de los elementos arquitectónicos de la cubierta del coro, y los elementos 10 y 11 , de acceso (Figuras $2 b$ y 9 ).

7.- El elemento número 7 constituye el límite occidental del coro alto y también uno de los extremos occidentales de todo el edificio monasterial. Se trata de un muro similar al elemento anterior, tanto en dimensiones como en tipo de fábrica, presentando como diferencia principal, frente al elemento número 6 , el hecho de ser completamente de nueva construcción, apoyando no sobre restos de la cámara anterior, sino directamente sobre el propio terreno, elevado de forma natural en esta zona. Por otra parte su estado de conservación es más deficiente, mostrando únicamente el relleno de sillarejo. El único elemento a destacar en esta parte es el número 12, que se comentará más adelante y que, como los que llevan los números 13, 14 y 15 sería de construcción simultánea a la del propio muro (Figuras 6 y 7$)$.

8.-El elemento número 8 constituye el límite septentrional del coro alto. Su fábrica sería básicamente idéntica a la de los dos elementos anteriores, los números 6 y 7 , constituyendo un muro de doble hoja, con un interior de relleno formado por mampostería de cantera y morrillo, oculto al interior de la cámara por un enlucido (elemento 21) y al exterior por una hoja de sillería isódoma bien trabajada y escuadrada, de la que aún pueden verse restos en la parte superior del muro. Por desgracia, como sucede también en el elemento número 6, este lienzo se conserva sólo parcialmente, habiendo desaparecido prácticamente la mitad del mismo (Figuras 6 y 9).
9.- Supondría un muro de contención destinado a asegurar la estabilidad del terreno sobre el que se situaba el coro y a dejar libre el espacio de la cámara anterior, que quedaría bajo el coro (Figura 7).

10.-Se trata de un pequeño vano rectangular, adintelado, que por su posición y dimensiones quedaría integrado en el interior de la cámara, en el conjunto lígneo de la sillería coral, a la que daría paso desde el exterior del coro, a través del muro meridional, directamente a su nivel alto (Figura $2 b)$.

11.-Supondría una de las últimas intervenciones en el espacio coral. Se trata de un pequeño vano cuadrangular situado a la izquierda del elemento 10, cuya forma regular impide pensar que se trate simplemente de un desperfecto causado por la ruina del muro. Su función es sin embargo desconocida, ya que estaría ubicado demasiado bajo como para ser un elemento de iluminación y es demasiado pequeño para constituir un acceso. Quizá en su día albergase un pequeño hueco de uso exclusivo para la cámara adyacente al coro y que, al desaparecer el mobiliario de éste, se haya perdido completamente su configuración (Figura 2b).

12.- El espacio del coro y la nave central se iluminaría a través del gran óculo que se abre en el muro occidental de la misma (elemento 7), una sencilla abertura circular abocinada y levemente moldurada con tres boceles que dibujan sendos círculos concéntricos (Figura 7).

13 y 14.-Constituyen los únicos restos del sistema de cubierta de la cámara. Ambos están formados por el arranque de varios nervios que apoyan en una ménsula, decoradas con un castillo la del lado meridional y con la cruz de Fernán González la del septentrional, adosada al espacio de confluencia de dos muros y reforzada al exterior por sendos contrafuertes de los que 
restan únicamente partes del núcleo de relleno. Se trata en ambos casos de cinco nervios correspondientes respectivamente a la molduración de los arcos adosados a los muros el primero y el último, al nervio crucero el central y a dos terceletes los dos intermedios, de lo que puede deducirse claramente el sistema de cubrición utilizado (Figuras $2 b$ y 7 ).

15.-Similar a los anteriormente descritos, pero adosado al lienzo hoy exterior del elemento 6, supone la utilización de una cubierta similar para la cámara adyacente, desde donde se accedería directamente al coro a través del elemento 10.

16 y 17.-Son los restos de las jambas de una puerta monumental abierta en la zona occidental del templo que constituye el acceso desde la iglesia a la cámara occidental. Son dos piezas de piedra embellecidas, en la parte que da a la iglesia, con un sencillo fileteado doble (Figuras 2a y 8).

18.-Se trata de la escalera que, desde la cerca que cierra el monasterio por su lado Norte, permite el acceso directo a la iglesia por su parte occidental, atravesando la cámara objeto de este estudio (Figura 9).
19.-Constituye la continuación del elemento 9 y como éste es un muro de contención destinado a asegurar el desnivel existente en la parte occidental de la iglesia, en este caso en su exterior, garantizando así la construcción de la escalera que baja desde la cerca hasta penetrar en el templo. Presenta una fábrica de sillarejo bien trabado similar a la de la cerca y, como ésta, se remata en lomo curvo (Figura 7).

20.- El número 20 es una pequeña hornacina pétrea abierta en el muro meridional de la cámara (elemento 1) y formada por dos piezas de piedra que le proporcionan un remate en cuarto de esfera (Figura 10).

21.- El elemento 21 es un revestimiento enlucido que cubriría los muros de la cámara en su interior y cuyos restos son todavía visibles en los elementos 6,7 y 8 . Su avanzado estado de deterioro no permite determinar si se trataba de un paramento ornamental, necesariamente muy simple, o de un sencillo enjabelgado, opción esta última más probable por el tono claro, seguramente blanco en origen, que puede verse en las partes conservadas (Figura 10). 


\begin{tabular}{|c|c|c|c|c|c|}
\hline № & Elemento & Fase & anterior a & coetáneo a & posterior a \\
\hline 1 & Muro Sur de la cámara occidental & I & & & \\
\hline 2 & $\begin{array}{l}\text { Muro Sur de separación entre la } \\
\text { iglesia y el cuerpo occidental }\end{array}$ & II & & & \\
\hline 3 & $\begin{array}{l}\text { Muro Norte de separación entre la } \\
\text { iglesia y el cuerpo occidental }\end{array}$ & II & & & \\
\hline 4 & $\begin{array}{l}\text { Pilar Sur adosado al muro oeste de } \\
\text { la iglesia }\end{array}$ & II & & $2,3,5$ & \\
\hline 5 & $\begin{array}{l}\text { Pilar Norte adosado al muro oeste } \\
\text { de la iglesia }\end{array}$ & II & & $2,3,4$ & \\
\hline 6 & Muro Sur del coro alto & III & & $7,8,12,13,14,15$ & 9 \\
\hline 7 & Muro Oeste del coro alto & III & & $6,8,12,13,14,15$ & 9 \\
\hline 8 & Muro Norte del coro alto & III & & $6,7,12,13,14,15$ & 9 \\
\hline 9 & $\begin{array}{l}\text { Lienzo de contención en lado oeste } \\
\text { de la cámara inferior }\end{array}$ & III & $6,7,8$ & & \\
\hline 10 & Puerta en muro Sur del coro alto & III & & & \\
\hline 11 & Vano en muro Sur del coro alto & III & & & \\
\hline 12 & Óculo en muro oeste del coro alto & III & & $6,7,8,13,14,15$ & \\
\hline 13 & $\begin{array}{l}\text { Ménsula, arranque de nervios y } \\
\text { arcos formeros del ángulo Suroeste }\end{array}$ & III & & $6,7,8,12,14,15$ & \\
\hline 14 & $\begin{array}{l}\text { Ménsula, arranque de nervios y } \\
\text { arcos formeros del ángulo Noroeste }\end{array}$ & III & & $6,7,8,12,13,15$ & \\
\hline 15 & $\begin{array}{l}\text { Ménsula, arranque de nervios y } \\
\text { arcos formeros del muro Sur por el } \\
\text { exterior }\end{array}$ & III & & $6,7,8,12,13,14$ & \\
\hline 16 & Jamba Sur de la puerta del templo & IV & & $17,18,19$ & \\
\hline 17 & $\begin{array}{l}\text { Jamba Norte de la puerta del tem- } \\
\text { plo }\end{array}$ & IV & & $16,18,19$ & \\
\hline 18 & Pavimento y escalera & IV & & $16,17,19$ & \\
\hline 19 & Murete Oeste de la escalera & IV & & $16,17,18$ & \\
\hline 20 & $\begin{array}{l}\text { Hornacina en muro Sur de la cáma- } \\
\text { ra inferior }\end{array}$ & IV & & & 1 \\
\hline 21 & Enlucido del coro alto & IV & & & $6,7,8$ \\
\hline
\end{tabular}




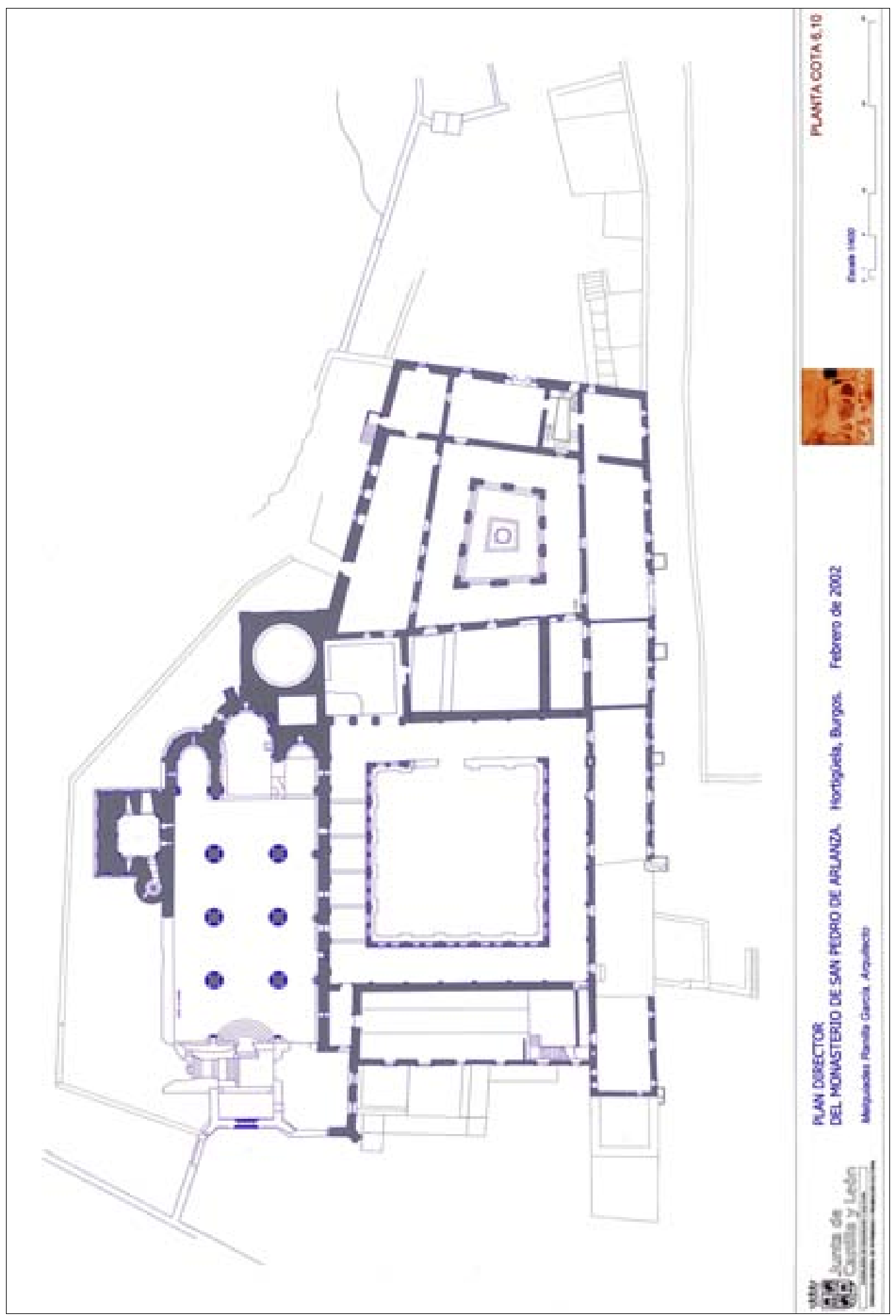

- Fig.1. Plano del Monasterio de San Pedro de Arlanza (Melquíades Ranilla García). 


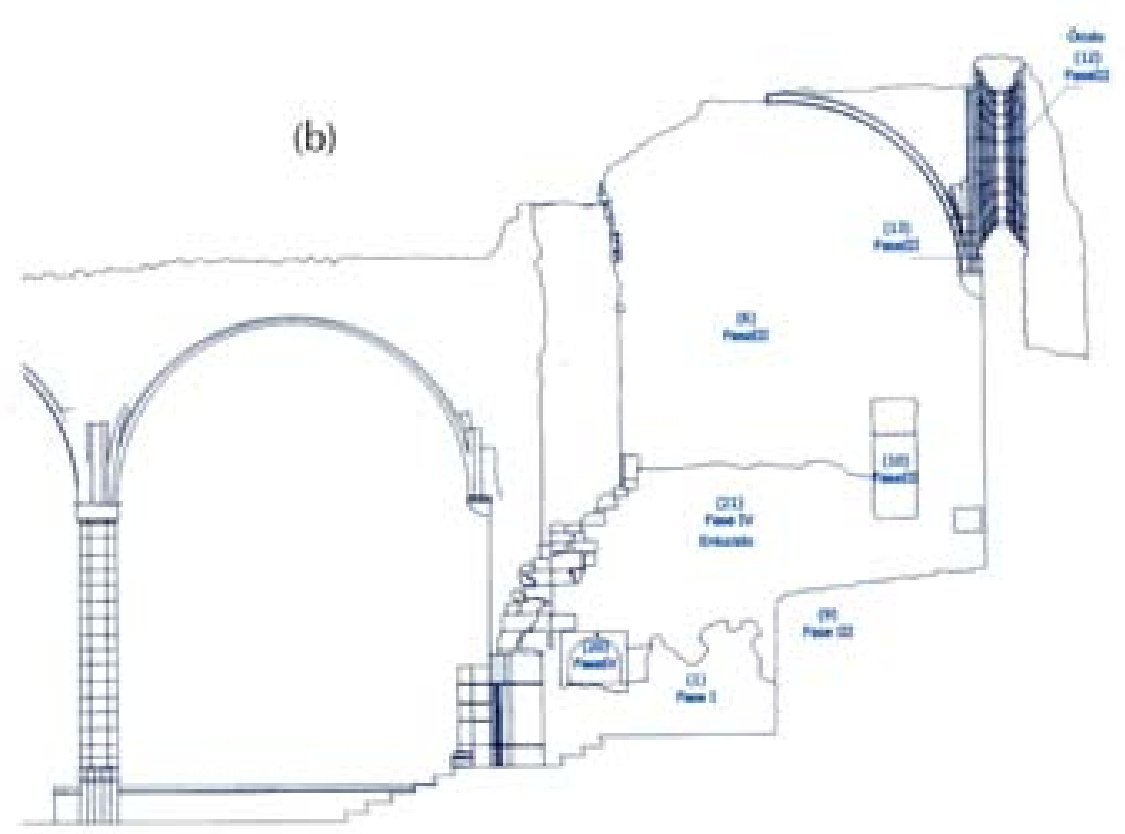

(c)

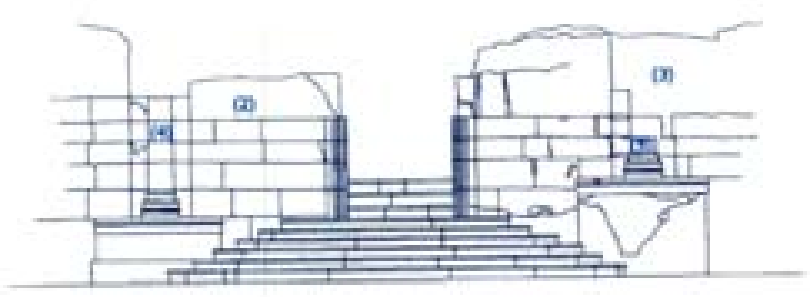

(a)
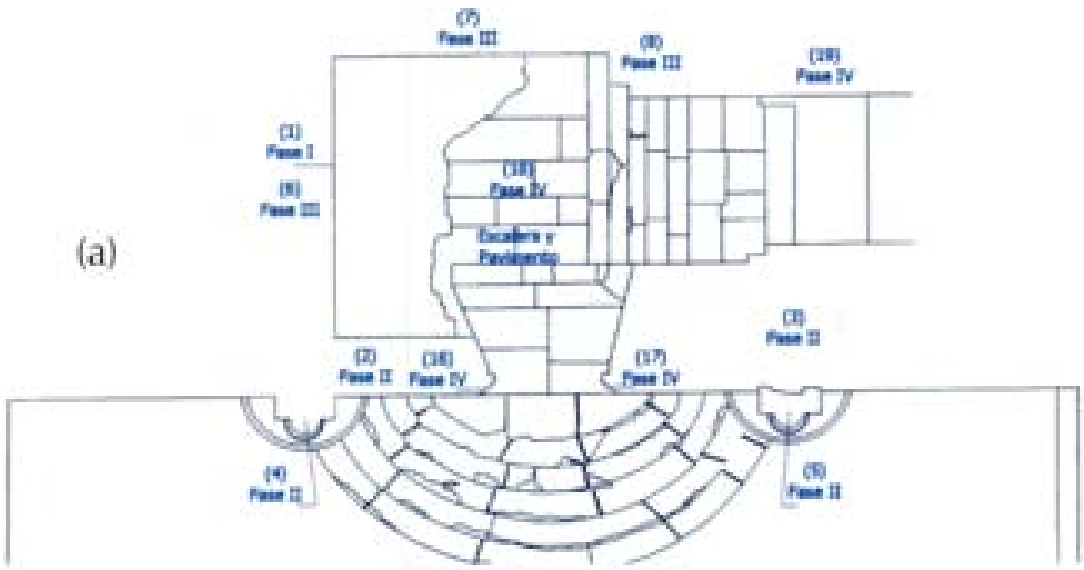

- Fig. 2. Cuerpo occidental. Planta (a), sección longitudinal (b) y puerta de acceso desde la iglesia (c). (Melquíades Ranilla García). 

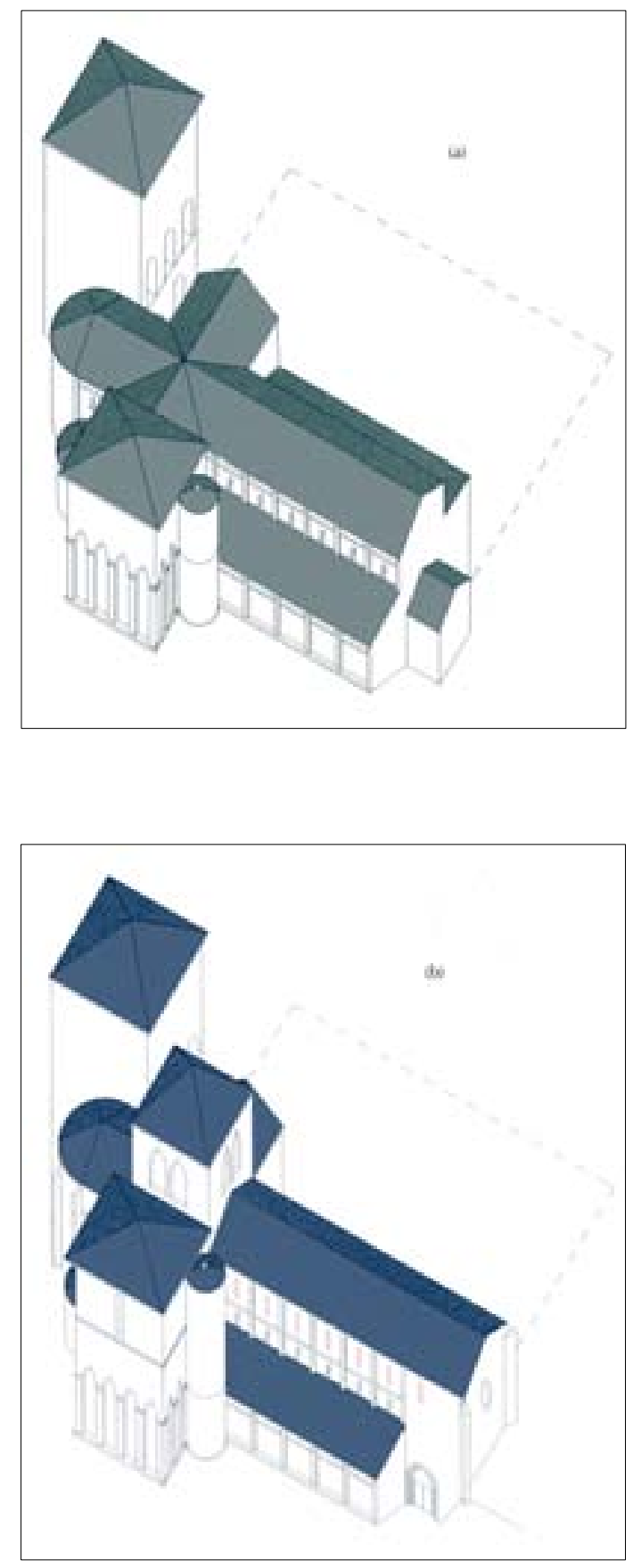

- Fig. 3. Reconstrucción de la iglesia en época románica (a) y en época moderna (b). (Melquíades Ranilla García).

(arriba izquierda, abajo izquierda)
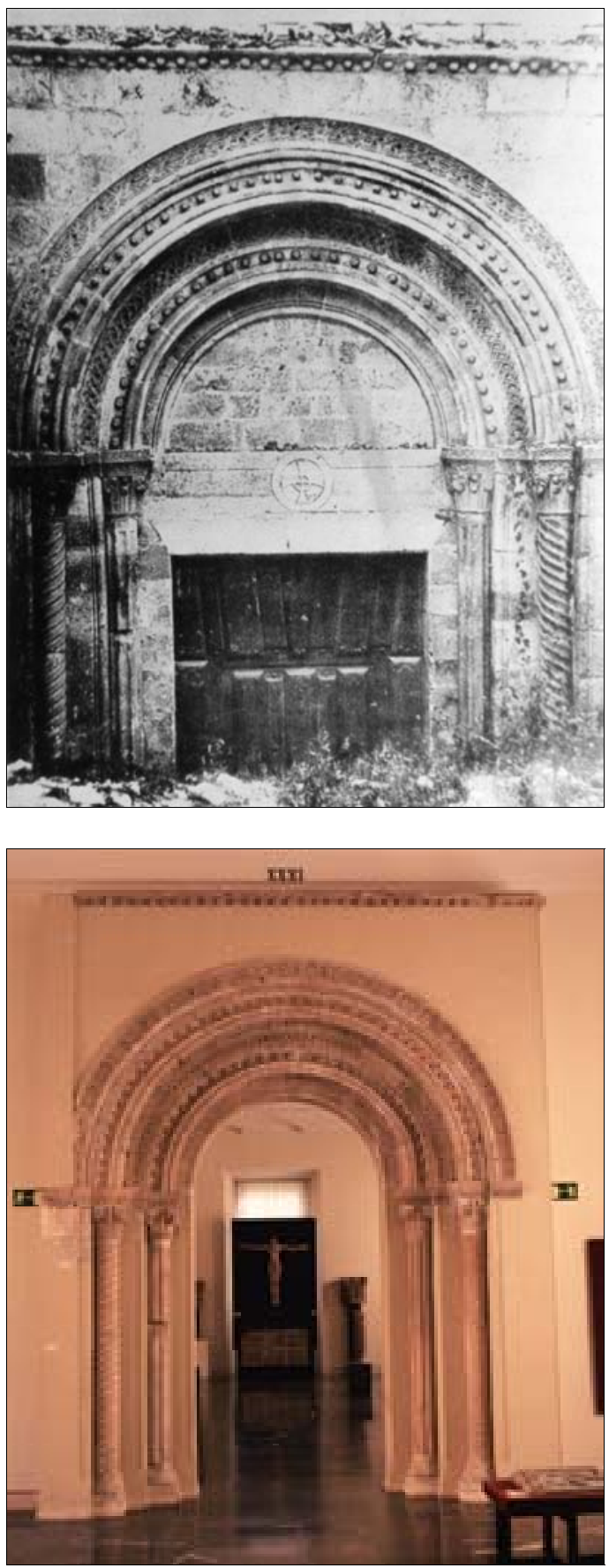

- Fig. 4. Puerta del cuerpo occidental en su ubicación original (R. AMADOR DE LOS Ríos, Las ruinas del Monasterio de San Pedro de Arlanza, Madrid, 1896).

(arriba derecha)

- Fig. 5. Puerta del cuerpo occidental. en su estado actual en el Museo Arqueológico Nacional (Archivo fotog. M.A.N). (abajo derecha) 

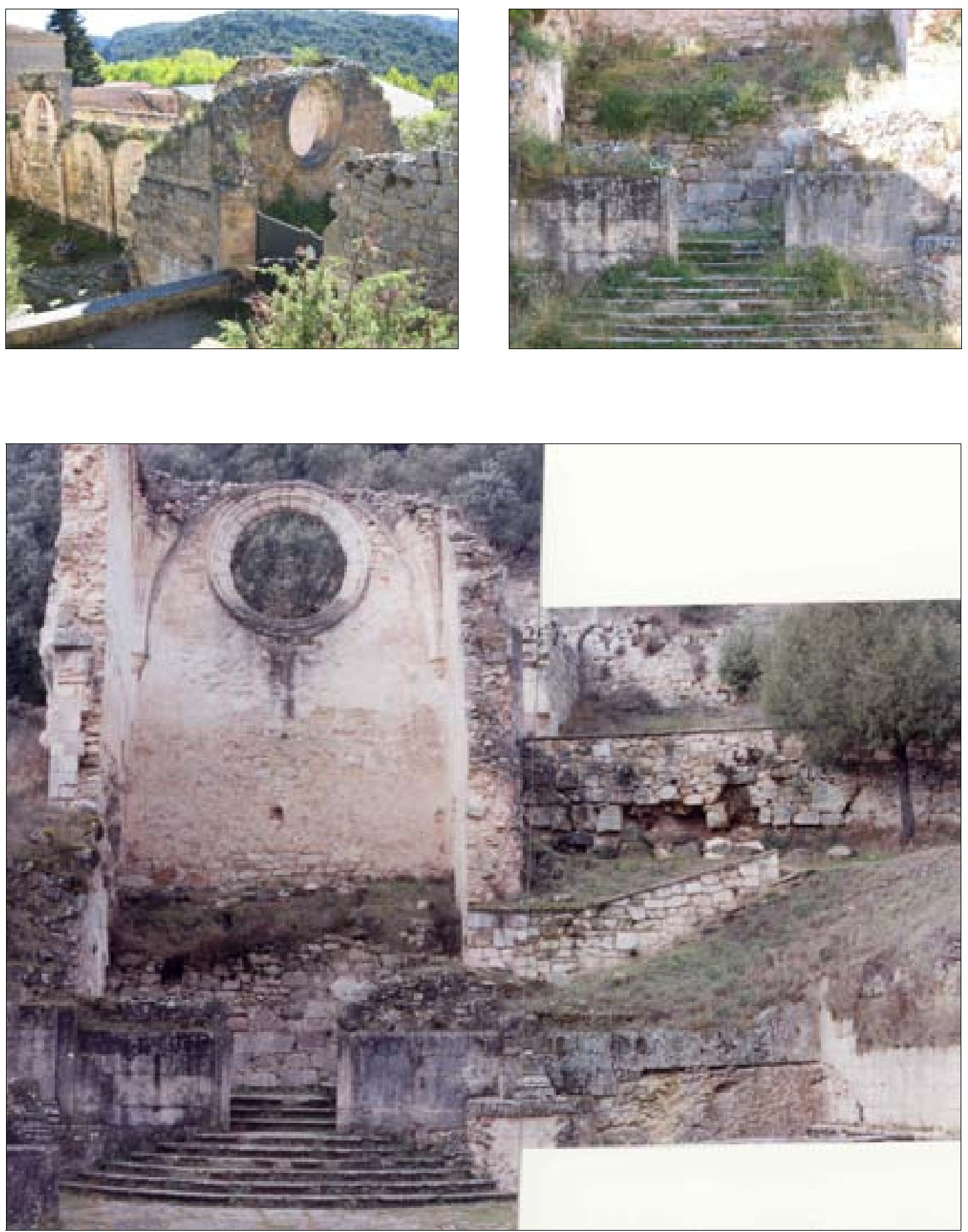

- Fig. 6. Detalle de la parte superior del cuerpo occidental desde el Oeste. (arriba izquierda)

- Fig. 7. Vista general del cuerpo occidental (abajo)

- Fig. 8. Acceso al cuerpo occidental desde la iglesia (arriba derecha) 

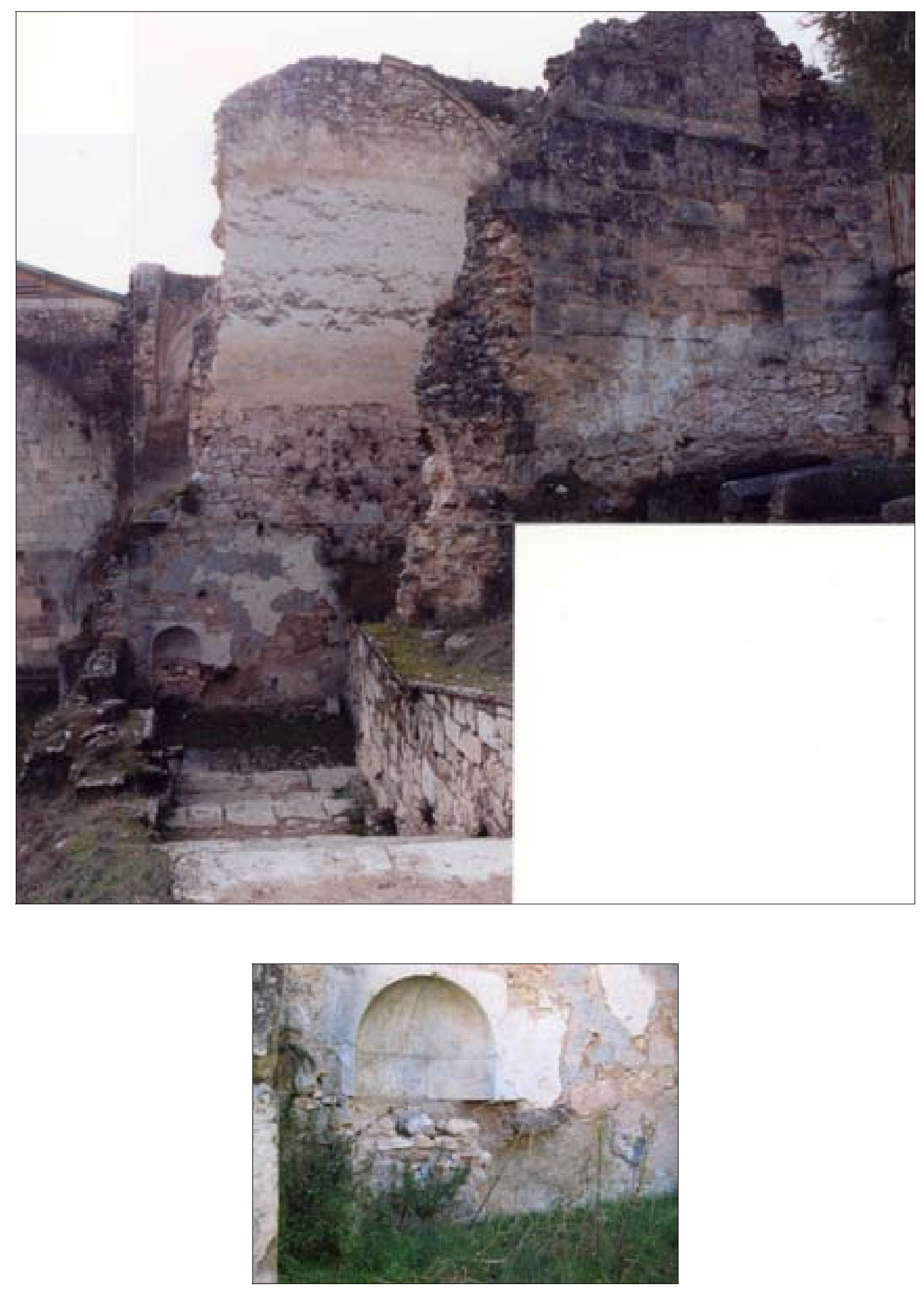

- Fig. 9. Bajada al cuerpo occidental desde el exterior de la iglesia (arriba)

- Fig. 10. Hornacina del cuerpo occidental (abajo) 